\title{
The Role of Government in Destruction Actions under the Theme of Environmental Utilization
}

\author{
Vica Jillyan Edsti Saija \\ Faculty of Law, Universitas Pattimura Ambon, Indonesia \\ Email: justitia_power@yahoo.com
}

\begin{abstract}
Desire to maximize all resources makes people try by all means and effort, from the most difficult to the easiest one to get abundant results. The original reason of fulfilling the needs of life then gradually became the desire to exploit more for unlimited wealth. This paper studies about government's actions in gold mining exploitation happens on Botak Mountain in Buru Island located in Maluku Province. Utilization of the land usually promise a tremendous income. No wonder many people are vying to take advantage of the resource, starting from the indigenous of Buru Island, to those who are from outside Maluku Province itself. The exploitation of the mine resource is done illegally with simple management processes, but the main problem is that the process used hazardous chemical materials for the environment. Mercury and cyanide are the two materials used in gold mining on Botak Mountain. Both of these chemicals are very harmful for the environment, plants, animals and humans. In addition, the method used in explaining this paper, is a normative method and the findings in this study that the local government has not been firm in addressing the issue of illegal mining, closing and reopening the mine without any law enforcement both preventively and repressively it will be useless because the environmental impact that is felt will affect many people.
\end{abstract}

\section{Keywords-Destruction; Environmental; Government; Utilization}

\section{INTRODUCTION}

Indonesia is popular with its rich natural resources. Both land and sea offers many extraordinary natural wealth. This extraordinary natural resources has been used not only for everyday human needs but it has been exploited remarkably in order to improve the standard living of human beings. Each region in Indonesia has its own natural wealth. Mines are one of abundant natural resources this country has been graced with. Almost all types of minerals could be easily found in this country. They have been managed in a simple way and even in more advanced ways by the community in which there has been cooperation between the government and the private sectors. In recent years, Maluku Province, one of the provinces in the eastern part of Indonesia which famous with its' characteristics as the archipelago area, become the concern worldwide because of the discovery of mining areas in the form of metal and gas, which in this paper will be discussed about the exploitation of gold mines located in Mount Botak in Buru District. The mine was once closed by the government but then start to operate again. Mining on this mountain is done by individual without permission, so they are illegal miners. These illegal miners are coming from community member around the mining area but some also come from outside of Maluku. This situation certainly become a concern for the local government to be able to discipline these illegal miners who works in the mining area of Mount Botak.

Exploitation of this mining definitely brings great profit to those who do the mining, but unfortunately the utilization has become destructive. The results of research conducted by Pattimura University researchers showed that the mining process used some materials that are harmful for the environment such as mercury and cyanide. The use of mercury and cyanide has different effect. The effect of using mercury on the environment for example can be seen slowly, few years or even ten years later while the impact of using cyanide can be seen directly and it even leads to an instant death. These findings should be a crucial and urgent problem for the government. Therefore the research question in this paper is focused on what can be done by the local government to solve the problem.

Previously, there had been research carried out related to law enforcement, but perhaps because there were no clear rules for the government to control, therefore these illegal mining activities continued with and there was no firmness from the local government. At present with the development of 
environmental damage that is getting worse and the enactment of regulations that support law enforcement by the local government, the regional government should be firm in taking steps to uphold the law, according to the author a 4 (four) year period is a long time to allow this problem. This is important to be discussed because of the dangers posed by illegal mining for the environment. So the authors conducted a study using normative methods and analytical descriptive approaches, and the researcher found that the government did not firmly resolve this problem for that law enforcement must be carried out in accordance with the regulations. Provides criminal sanctions for illegal miners, closes and revitalizes the environment, and provides clear permits in accordance with procedures.

\section{RESEARCH METHOD}

This paper uses normative methods. Normative methods are a scientific evaluation procedure to express the truth based on the logic of legal science from the normative side built on scientific discipline and the ways of normative law science, namely the law whose object is law itself [2]. In this study a descriptive-analytical research approach was used in which the results of the literature study were then analyzed and discussed systematically and then described to facilitate conclusions, and analysis techniques uses in this writing are qualitative analysis techniques. Legal material consisting of primary is the legislation uses among others The 1945 Constitution of the Republic of Indonesia, Law Number 4 of 2009 on Mineral and Coal Mining, Law Number 32 of 2009 on Environmental, Protection and Management, Law Number 23 Year 2014 on Regional Governance, Regional Regulation Number 18 Year 2014 on Maluku Coals and Minerals Mining Management, and secondary materials consist of the opinions of legal experts, legal journals, legal books, and the internet.

\section{RESULT AND DISCUSSION}

As a part of nature, environment provides a livelihood for human being. A clean and healthy environment provides a healthy life, a comfort to enjoy, and is a source of life for all human beings. Article 28H Paragraph (1) of the 1945 Constitution of the Republic of Indonesia states that "Every person shall have the right to live in physical and spiritual prosperity, to live and to obtain a good and healthy environment and to be entitled to health services." This shows that clean and healthy environment is a right owned by every Indonesian, and it is also a special right. While according to Law Number 32 Year 2009 on Environmental, Protection and Management, the definition of the environment is totally of space with all materials, resources, situation and creatures, including human beings and their behavior that influence the nature continuation of livelihood and human welfare as well as and other creatures. With the definition, it can be concluded that the environment has a broad understanding, not only related to the natural space but also the living things.

Maluku Province is one of the provinces in Indonesia which has many islands, thus the sea area is wider than its land area. The land area consisting of small and large islands. The largest island in Maluku is Seram Island which is $17.100 \mathrm{~km}^{2}$, then Buru Island with an area of $9,505 \mathrm{~km}^{2}$. With this numbers, it can be concluded that the land where the living creatures live is smaller than the seas surrounding it. Therefore the polluted soil due to inappropriate utilization will definitely threaten the life of all creatures inside.

According to King Wael Mansyur, a traditional leader of Buru District, the Local Government has issued Mining License for Individual since 2013 [3]. However, prior to 2013, the community has been engaged in mining activities since gold was first discovered in 2011. It is estimated that in 2012, 2.5 ton of gold were being produced every day. The mining is done not only by the people around but also from outside Maluku. It is conducted simple by digging a 5-10 meter hole for the miners to enter and dredge the gold inside. After that, the gold obtained will be processed using a tromol machine. Processing the gold with this tromol machine is the simplest and cheapest way of processing the gold. This machine even could be made by ourselves because it is made of iron or steel barrel and serves as a destroyer to destroy and filter the gold from golden rock.

Tromol machine is used as a medium to take the gold dust in the mud by using mercury. The more mercury included the better the results will be. At Botak Mountain, the mining is done with a system of immersion and dumping. Furthermore, they are not only using mercury but also cyanide. The research conducted by Universitas Pattimura researchers in 2012-2017 shows the miners use these two dangerous chemical in a very high level that will endanger the environment. In fact, The Botak Mountain case can be a tragedy like Minamata tragedy. It is very possible that in the next 10 years Minamata disease can attack the community. Mercury poisoning can cause paralysis, mental illness and even death, while poisoning in pregnant women can lead to defects in 
the fetus and miscarriage. The disposal of the waste water full with cyanide or mercury is also done carelessly, resulting in pollution happened in the Anahoni River.

Water, soil, and human samples taken around mining areas has been contaminated with mercury. The most frightening thing is that in early 2018, some livestock had died after drinking water from the nearby area that has been contaminated by mercury and cyanide. The contaminated river flows into the sea and polluted all the living creatures inside in the sea. Then when people eat food from the sea, it will affect their health, and if it is not managed soon, then in some future time, the impact of contamination will not be only in the area around the mining but broader. However, according to the Law Number 32 in 2009 Article 60, everyone is prohibited to dump any kind of waste and /or materials without permission. Dumping, according to Article 1 number 24, related to activities of throwing, placing and / or putting waste and / or materials in a certain amount, concentration, time and location with certain requirements into environment. Therefore, if this kind of activity is conducted, then everyone who committed into this action will be punished with a maximum 3 (three) years imprisonment and a maximum fine about Rp. 3.000.000.000,00 (3 Billion Rupiahs) according to Article 104.

In addition, when the mine first opened, all the trees around the mining area were cut down, destroying the ecosystem nearby and the habitat of the animals and plants. Besides the ecological impact, gold mining on Mount Botak brings other negative effects both for health and sociology. Sex trading activity increased HIV/AIDS spreading, lack of clean water has caused skin diseases [8]. Some people even have to lose their lives due to competition to get gold. The conflict also happened between local people about land ownership and conflict with miners who did not have permits or were illegal miners. The number of problems that arise just like a curse behind grace.

The consequences described above, if not stopped, will bring more negative impacts on the environment and the people. The utilization that should be done to bring prosperity caused miserable wounds for the environment, whereas mining must pay attention to the environment as a prerequisite for the issuance of licenses and even post-mining reclamation must be done so that environmental sustainability is maintained. All consequences happened to the environment can be categorized as destructive actions that should be sanctioned against those who are found to have committed such destructive actions. Therefore, government should take an urgent and strict action to solve the problem. Based on the 1945 Constitution of the Republic of Indonesia, Article 33 Paragraph (3) states that the earth, water, and natural resources contained are controlled by the state and used for the greatest prosperity of the people. This arrangement raises the concept of state control which refers to the meaning of the rule of law in the public sphere, this power is related to authority.

Government authority is based on attribution laws, one of them is Law Number 4 Year 2009 on Mineral and Coal Mining. Mineral mining according to this Act is a. radioactive mineral mining; $b$. metal mineral mining; c. non-metallic mineral mining; and d. rock mining. One form of metal mineral is gold, thus gold mining can be categorized as part of metal mineral mining. The law clearly provides an authority to the local governments. The local government has the authority in granting licenses for Mining Effort License (IUP) and Community Mining License (IPR).

Based on Article 7 paragraph (1), the authority of the provincial government in the management of mineral and coal mining, among others are to make provincial law and regulation; to grant Mining Effort License (IUP), guide, resolve community conflicts and supervise mining efforts that activities on the boundaries of district/city and/or sea territorials from 4 (four) miles up to and including 12 (twelve) miles; to grant Mining Effort License (IUP), guide, resolve community conflicts and supervise the mining efforts with direct environmental impacts on the boundaries of district/city and/or sea territorials from 4 (four) miles up to and including 12 (twelve) miles; to conduct inventory, investigation and research and exploration in order to obtain mineral and coal data and information within their authorities; to develop and enhance community participation in mining efforts with the focus also on environmental sustainability; to guide and supervise post-mining land reclamation. Maluku Province itself has a regional regulation that arrange about Minerals and Coal namely Regional Regulation Number 18 Year 2014.

The Article 8 paragraph (1) letter c, the authority of the regency / municipality in the management of mineral and coal mining, among others are: to grant Mining Effort License (IUP) and Community Mining License (IPR), guide, resolve community conflicts and supervise the mining production operation whose activities are within the boundaries of the district/city and/or sea territorials up to 4 (four) miles. In addition, district/municipal governments should expand and empower local communities related with mining efforts that focus on 
environmental protection and sustainability, then develop and enhance the value-add and benefits of mining business activities in an optimal manner. The Regent or Mayor provides Community Mining License (IPR) especially for the locals, both individuals and community groups and/or cooperatives. Then the Regent/Mayor can delegate the authority to implement the people mining license to the district head according to the provisions of the laws and regulations, and in order to obtain the People Mining License (IPR), the applicant must submit the application letter to the regent/mayor.

If the claim from King Wael that the Mining in Mount Botak had obtained a permit in the form of IPR (People/Community Mining License) in 2013 then the consequence is that the licensor should supervise the permits issued, then with the supervision it would minimize even prevent all kind of destructive actions in the minefield. In addition, if the licensee does not comply with the obligations, they may be sanctioned. Therefore, it could be concluded that supervision is one of the preventive actions that can be done by the local governments. However, after the enactment of Law Number 23 Year 2014 on Regional Governance, the District/City Government no longer has the authority to administer government affairs in mineral and coal mining since October $2^{\text {nd }}, 2014$ as stated in Joint Circular Letter Number 04.E/30/DJB/2015 on the Implementation of Government Affairs in Mining and Coal Mining. Therefore, every article in Law Number 4 Year 2009 and its enforcement regulation governing the Regent/Mayor's authority has no binding legal force.

In relation to IPR/Community Mining License, the area for 1 (one) IPR can be given to: $a$. individuals for maximum of 1 (one) hectare; $b$. community groups for maximum 5 (five) hectares; and/or cooperative for at most 10 (ten) hectares. (2) IPR shall be granted for a maximum period of 5 (five) years and may be extended. Article 69, IPR Holders are entitled to: a. receive guidance and supervision about occupational safety and health, environment and mining technic and management from the Government and/or regional governments; and $b$. get capital assistance according to the provisions of legislation.

IPR holders have obligations including: $a$. conduct mining activities no later than 3 (three) months after the IPR is issued; $b$. comply with the laws and regulations about mining safety and healthenand also vironmental management according to the standards; $c$. Take care of the environment together with the local governments; d. pay fixed fees and production fees; and e. submit reports on the implementation of mining business activities periodically to the IPR giver. In addition to liabilities, IPR holders in doing the mining activities must comply with the terms of the mining technical requirements.

Furthermore, related to IUP (Mining Efforts License), based on Law Number 4 Year 2009, it consists of two stages: a. Exploration of Mining Efforts License includes general investigation, exploration and feasibility studies; b. Production Operation of IUP includes construction, mining, processing and refining activities, as well as transportation and sales. The IUP is granted by the regent/mayor if the IUP Area (WIUP) is within a regency/municipality territory; $b$. governor if the WIUP falls within the district/municipal territory within 1 (one) province after obtaining a recommendation from the local regent/mayor in accordance with the provisions of legislation; and c. Minister if the WIUP is located across the province after obtaining a recommendation from the local governor and regent/mayor in accordance with the provisions of legislation. IUPs are granted to business organization, cooperatives and individuals. The Government and regional governments in accordance with their respective authorities are obliged to announce the plan of mining business activities in WIUP and provide IUP of Exploration and Production Operation IUP to the public openly. Then business organizations, cooperatives, and individuals conducting mining operations shall meet all the administrative requirements, technical requirements, environmental requirements, and financial requirements.

In 2015, when President Joko Widodo visit the village of Waepo in Buru District, he instructed to close the mining in Mount Botak. The consequence of a unitary country is that the ultimate responsibility of the administration is in the president, in which the governmental affairs which are handed over to the region are derived from president. With this instruction, 3 (three) decisions had been issued by Maluku Provincial Government which are the decision to form a team to close Mount Botak temporarily, a special decision to discipline all illegal miners, and a decision for the assessment team or socialization. Based on the decision, the mining in Mount Botak was temporarily closed, and then security forces including the Army, Police and civil Service Police Unit had been deployed to conduct sweeping and guarding the mining area. However, in early 2017 , the security forces were withdrawn from the mining area, and it then has become an opportunity for illegal miners to re-enter the mining area. 
Based on the Decision of the Governor of Maluku Number 383 Year 2016 on November 23rd, 2016 [1], the mining permit granted to PT. Buana Pratama Sejahtera based on Law Number 23 of 2014 on Regional Government. In accordance with the mandate of the attachment of this Act, there are 7 (seven) provincial authorities of mineral and coal sub-sector. Some related to the IUP of gold mine which is the issue of metal mineral and coal IUP in the framework of domestic investment in IUP areas within 1 (one) provincial area including sea area up to 12 miles. IPR issuance for metal mineral, coal, non-metallic minerals and rocks commodities in the community mining areas. With the existence of all these provisions, then the rightful authority to issue IUP is the Provincial Government.

License to PT. Buana Pratama Sejahtera does not necessarily stop the freedom of illegal miners to carry out its actions. The withdrawal of security forces from the Mount Botak area become loopholes for them to return. It has become public concern that the use of mercury and cyanide will lead to wider pollution in Buru Island. The reason forced the Regent of Buru District, Ramly Umasugi to write to the Governor of Maluku as the leader of Maluku Province on January 5th, 2018 to close the mining in Mount Botak as well as report that about 13,000 miners from outside of Maluku has come and do illegal mining (Tribun Maluku : 2018). Based on the report, the Governor of Maluku directly made the decision to temporarily close the mining area of Mount Botak

Government action based on Regional Regulation of Maluku Province Number 18 Year 2014 in Article 63 that mining business activities may be temporarily suspended if: (1) there is a force majeure such as war, civil riot, rebellion, epidemic, earthquake, flood, fire, and other natural disasters beyond human capability; (2) obstructing circumstances such as blockades, strikes, labor disputes beyond the mistakes of IUP or IUPK holders and the provisions of legislation issued by ministers that impede the ongoing activities of mineral or coal mining enterprises; and (3) condition of carrying capability of the environment that is if the condition of environmental area cannot bear the burden of mineral and/or coal production operation activity conducted in its territory.

In relevant with previous experience, it can be concluded that temporarily closing the mine will not be effective because if there is an loophole then illegal miners will return again. Therefore the local government must sanction all the illegal miners under the terms of legislation. In addition, license holders who used mercury and cyanide should be subject to sanctions. This action hopefully will provide a deterrent effect to the perpetrators or can be said as a form of repressive efforts to the problems that arise.

If the Perpetrators are illegal miners (without the license of IUP, IPR or IUPK), then according to The Law Number 4 Year 2009 Article 158, they will be punished with maximum 10 years imprisonment and maximum fine about Rp. 10.000.000.000,00 (Ten Billion Rupiahs) and based on the provisions in Regional Regulation Number 18 Year 2014, there are two types of sanctions given, they are administrative sanctions and criminal sanctions. Administrative sanctions are in form of written warning, temporary suspension of IUP of Mineral and Coal Production Operations; and/or revocation of IUP. Moreover, the criminal sanctions are, among others, as in Article 101 that every person who conducts mining efforts without IUP shall be punished with a maximum imprisonment of 10 (ten) years and a maximum fine of Rp 10,000,000,000.00 (ten billion rupiah).

Furthermore, in Article 103 paragraph (1), every person who does exploration without owning IUP shall be punished with a maximum of 1 (one) year imprisonment and a fine of not more than $\mathrm{Rp}$ $200,000,000.00$ (two hundred million rupiah). As for the IUP holder, there are several obligations that should be done, they are: (a) applying the rules of good mining techniques; (b) managing finances according to Indonesian accounting system; (c) increasing the value-add of mineral and/or coal resources; (d) developing and empowering local communities; and (e) Following the tolerance limits of environmental carrying capability. In addition, they shall submit all data obtained from the exploration and production operations to the Governor, and shall provide periodic written reports on the work plan and implementation of mineral and coal mining business activities to the Governor. Therefore, if IUP Holders who deliberately submit incorrect reports or convey false statements, they shall be punished with imprisonment of not more than 10 (ten) years and a fine of not more than $\mathrm{Rp}$ $10,000,000,000.00$ (ten billion rupiahs) in accordance with Article 102.

Furthermore, if the license is issued by the local government, supervision of the license must be conducted. Before the license or permit is issued, there are some requirements must be met, one of which is the environment. Both Exploration IUP and Production Operation have a requirement to make a statement to obey the provisions of laws and regulations in the field of environmental protection and management.

Therefore, based on Law Number 32 Year 2009, there are pollution and environmental damage 
prevention instruments which basically are also instruments of environmental management because environmental management is also intended to prevent and overcome the problem of pollution and environmental damage. These instruments include: (1) The Study of Environmental Strategic (KLHS), (2) spatial plan, (3) environmental quality standard, (4) standard criteria of environmental damage, (5) Analysis About Environmental Impact (AMDAL)), (6) environmental management and environmental monitoring efforts (UKL-UPL), (7) licensing, (8) economic instruments, (9) environment-based legislation, (10) environmental-based budgets, (11) environmental risk analysis, (12) environmental audit.

The Act mandates that every business and/or activity required to have an AMDAL and UKL-UPL shall have an environmental license issued based on the environmental feasibility or recommendation of UKL-UPL. With the requirements related to the environment as a form of prevention against environmental damage, it can be concluded that this is a preventive effort that could be done before the mining permit issued.

Previously, in 2012, there was a research related to Law Enforcement on Mining Activities in Mount Botak with findings to make a product of regional law as the answers to legal vacancies and mining license [4], [5]. However, after the regional regulation have been made, there has not been any kind of strict actions from the government to the illegal miners on Mount Botak. In fact, the number from that time the Law has been passed to the very recent days, is about 4 (four) years. The duration is quite long for the government to put the strict actions against all the illegal miners.

\section{CONCLUSION}

From this research, the finding shows that the role of government in solving the problems in Mount Botak is not firm enough. As the result of this action, all the illegal miners felt free to act according to what they like. Therefore, The Law Enforcement Effort should be carried out to these illegal miners with sanctions. Furthermore, in order to fix their destructive actions, the government should close the mining area and work with some experts in mining, environment and others subject related to this problem as a part of revitalization process of environment. Then, as a part of taking control, the local government should issue the mining license to whoever following the right procedure and enforcing administrative law in term of supervising. The government should enforce the license holders to conduct mining business services such as consultation, planning, implementation and testing the equipment and providing criminal sanctions if a violation occurs after permission is issued.

\section{ACKNOWLEGMENT}

The author would like to thank the Faculty of Law Universitas Pattimura Ambon for supporting this work and for organizing the International Conference on Indonesia Legal Studies Faculty of Law Universitas Negeri Semarang.

\section{REFERENCES}

[1] Fana Suparman. Penambang Liar Kembalin Serbu Gubung Botak. http://www.beritasatu.com/kesra/410801penambang-liar-kembali-serbu-gunungbotak.html. accessed on 11 June 2018.

[2] Jhonny Ibrahim. Teori dan Metode Penilitian Hukum Normatif. Banyumedia: Malang, 2008.

[3] Galih Gumelar. Masyarakat Desak Pemerintah Buka Kembali Tambang Gunung Botak. https://www.cnnindonesia.com/ekonomi/2016061 3141055-85-137753/masyarakat-desakpemerintah-buka-kembali-tambang-gunungbotak, , 2016. accessed on June 2018.

[4] Nirahua, S E M. 2012. Penegakan Hukum Terhadap Aktifitas Penambangan Emas Di Gunung Botak. https://fhukum.unpatti.ac.id/htnhan/207-penegakan-hukum-terhadap-aktivitaspenambangan-emas-di-gunung-botak. Accessible to date 11 June 2018.

[5] Nirahua, S E M. "Problematika Yuridis Kewenangan Pemerintah Daerah di Bidang Perizinan Dalam Pengelolaan Sumber Daya Alam Wilayah Laut". PhD Dissertation. Makassar: Universitas Hasanuddin, 2010.

[6] Rahmat Rahman Patty. 2012. Tiap Hari 2,5 Ton Emas Dikeruk Dari Gunung Botak. https://regional.kompas.com/read/2012/10/08/094 64099/Tiap.Hari.2.5.Ton.Emas.Dikeruk.dari.Gun ung.Botak. Accessible to date 11 June 2018.

[7] Saija, Vica J E. "Wewenang Pemerintah Daerah Dalam Pemberian Izin Lingkungan Hidup". Sasi 20(1): 68-80, 2014.

[8] Tahamata Lucia. 2015. Penambangan Emas di Gunung Botak, Kajian Hukum Lingkungan. https://fhukum.unpatti.ac.id/hkminternasional/360-pengelolaan-penambanganemas-di-gunung-botak-kajian-hukum-lingkungan. Accessible to date 11 June 2018.

[9] Takdir Rahmadi. Hukum Lingkungan di Indonesia, Rajawali Pers: Jakarta, 2013.

[10] Teras Maluku. 2018. Tiga Sapi Mati Setelah Minum Limbah Bahan Kimia Pengolahan Emas Ilegal Gunung Botak. 
https://terasmaluku.com/tiga-sapi-mati-setelahminum-limbah-bahan-kimia-pengolahan-emasilegal-gunung-botak/. Accessible to date 11 June 2018.

[11] Tribun Maluku. 2018. Penambangan Emas Ilegal Digunung Botak Harus Ditutup. https://www.tribunmaluku.com/2018/02/penambangan-emas-ilegaldi-gunung-botak.html, accessible to date 11 June 2018.

[12] The 1945 Constitution of the Republic of Indonesia

[13] Law Number 4 of 2009 on Mineral and Coal Mining

[14] Law Number 32 of 2009 on Environmental, Protection and Management

[15] Law Number 23 of2014 on Regional Governance

[16] Regional Regulation Number 18 of 2014 on Maluku Coals and Minerals Mining Management 